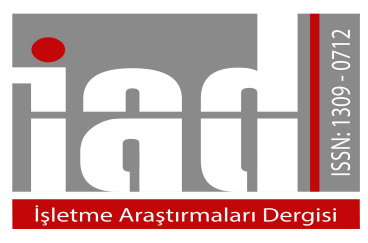

\author{
İşletme Araştırmaları Dergisi \\ Journal of Business Research-Turk \\ 10/3 (2018) 33-52
}

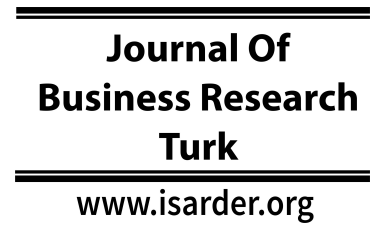

\title{
Investigation Root Causes of Labour Turnover Problem in Seaport Logistics Sector
}

\author{
Ünal ÖZDEMIR \\ Mersin University \\ Faculty of Maritime \\ Department of Maritime Business Administration \\ Campus of Tece, Mezitli- Mersin / Turkey \\ orcid.org/0000-0001-6865-9977 \\ unalozdemir@mersin.edu.tr
}

\begin{abstract}
Labor turnover is a phenomenon with negative consequences in the field of seaport handling and operations. This study aims at determining the causes of labor turnover and proposing alternative solutions for companies and logistic firms that are in charge of seaport cargo handling work. The causes and relations among the factors that are effective in labor turnover problem were determined using fuzzy DEMATEL and the related alternatives were analyzed by fuzzy TOPSIS technique. The results of the study revealed that some causes of labor turnover in seaports could be summarized as "low wages", "unguaranteed jobs", "limited career opportunities" and "unwelcomed managers". As alternatives to the labor turnover problem; "bonus pay", "career opportunities" and "offering partnership" may be considered to overcome the problem. The study is based on data from expert evaluations obtained from the questionnaires. Finally, some recommendations are made to diminish the labor turnover frequency in seaport companies.
\end{abstract}

Keywords: Seaport companies, Labor turnover, Fuzzy DEMATEL, Fuzzy TOPSIS.

\section{Introduction}

Labor turnover can be described as changes in number of workers in both private and public companies due to layoff, job quiting or new employments. The reason for starting or quiting a job can be various (Blau and Boal, 1987; Jaros, 1995; Çakar and Ceylan, 2005; Arocas, 2008). By analysing the rates of labor turnover in logistic companies, it can be easily noticed that human resources departments are mostly engaged with employments problems by spending too much time to avoid any intteruption in workflow process. In order to avoid from problems that may cause a strategic failure in seaport management productivity, causes of labor turnover problem should be clearly identified and documented. Job quitting decision can e caused by many reasons but generally, it might be classified as "willingly" or "unwillingly" based on experience of the workers (Cheng and Brown, 1998). Regardless of any reason and incidence, labor turnover will definitely affect the related management workflow of the 
business. As it is for many commercial sectors, labor turnover should definitely be investigated in maritime transportation as it currently creates unforeseen risks in terms of seaports economic efficiency. The major problems related to labor turnover in seaport companies are longer working hours, accidents and low quality service. Despite to increasing maritime logistic traffic with very high accelaration rates, many seaport companies are now capable of handling cargo with fast and efficient way at relatively aceptable low costs (Esmer, 2010; Jiang et al., 2012; Longo et al. 2015; Özdemir, 2016). In order to increase the net profit, the companies are tending to limit the total number of workers engagaed with cargo handling in seaports (Llacer, 2006; Longo et al. 2015). Thus, it means that the importance of each avaliable worker increases in terms of the company as there is not always possible to substitute the empty position with equal proficiency and experience. Such problems have to be also condered by personal management units of the firms. Moreover, unexpected job quitting, orientation of new workers, the period of gaining necassary experience, increasing insurance expenses, training expenses and the lose of prestige in market could also lead higher costs and longer working hours (Gambardella, 2001; Loi, Hang-yue and Foley, 2006). There is always a risk of spreading the private company information to other competitors in port operation market after stop working for that company. It should also be taken into account that the loss of an employee may not be able to be balanced by a new worker due to the lack of necassary experience and training. This is a challenging procedure as almost all of the seaport management enterpireses are private organizations (Scott et al., 1999; Griffeth et, al. 2000). Meanwhile, seaport are the areas with very high occupational accident rates. Based on seaport accident reports, most of the incidents are somehow referred to new and unexperienced workers (Danacı and Kişi, 2014; Özdemir, 2016).

Human factor is very important in maritime industry and it can be considered the focal centre of the seaport workflow process. Therefore, laborturnover in seaport business is one of the key factors governing the overall productivity of the active firms in the sector (Oral et al. 2007; Bruzzone et al. 2011; Jiang et al. 2012). Labor turnover can generally be considered as a phenomenon with negative and unwanted consequenses for the seaport companies. Rising costs, lower productivity rates and negative moral conditions of the workers are some of them to mention here (Cheng and Brown, 1998; Igbaria and Guimaraes, 1999; Arocas and Campis, 2008; Ting, 2013).

This study aims at determining the factors that lead to job quitting and related steps for solutions as well as deciding on labor turnover rates in seaport companies engaged with cargo handling business. There are many complex parameters related to labor turnover problem in seaport companies. Multiple Criteria Decision Making (MCDM) approaches are proved to be very effective in solving complex decision in management, industry and environmental issues. In order to analytically analyse the labor turnover problem in seaports, the Fuzzy MCDM approach can be followed (Liang, 1999; Kazemian, 2002; Zhang and Lu, 2002; Chou, 2007).

In this study Fuzzy MCDM techniques are used to determine the factors and alternatives that can be used to solve labor turnover problem in seaports. To define the order of related criteria, The Decision Making Trial and Evaluation Laboratory (DEMATEL) technique was applied by calculating weight of each factor to obtain the importance degree of the all criteria. Furthermore, the alternatives were also defined using the Fuzzy Technique for Order Preference by Similarity to Ideal Solution (FuzzyTOPSIS) 
method. The authors suggested an analytical approach to overcome the labor turnover problem in port management and service industry.

\subsection{Literature Review}

Reviewing the literature on labor turnover has shown that limited change in total number of workers in business enterprises can help to increase the short term productivity of a company. But, if the rate of laborturnover reaches a higher certain level then the outcomes will be definetely negative for the employer (Croasdell, 2001; Tuna; 2007; Lapointea and Vandenberghe, 2017). In spite of the fact that, seaport companies suffer from labor turnover problem, the lack of scientific studies on this maritime sector were not studied analytically in literature. The most of the avaliable studies on labor turnover are from the health or tourism sectors and mainly dealing with motivation startegies for overcoming extensive labor tunover in the market. Some recent studies on laborturnover are documented in Table 1.

Table 1. Similar studies reported in literature

\begin{tabular}{|c|c|c|}
\hline Business Space & Research Interests & Author \\
\hline Management & Job scope and career & Lapointea and Vandenberghe (2017). \\
\hline Tourism & the casino industry & Lia et al. (2017) \\
\hline Education & Teacher turnover & Hanusheka et al. (2016) \\
\hline Transportation & Bus Driver, coach industry & Lannooa and Verhofstadt (2016) \\
\hline Health & Nurse Turnover & Kovner et al. (2016) \\
\hline Health & Hospital Physicians & Tziner et al. (2015) \\
\hline Education & Faculty members' turnover & Rahim et al (2015) \\
\hline $\begin{array}{l}\text { Service } \\
\text { organization }\end{array}$ & Food Service & Jung and Yoon (2014) \\
\hline Social Services & Public child welfare workers & Kruzich et al (2014) \\
\hline Business & CEO turnover and shareholder wealth & Ting (2013) \\
\hline Music Industry & Music therapist's turnover & Kim et al. (2013) \\
\hline Labour Market & Worker's contract & Centeno and Novo (2012) \\
\hline Oil sector & Turnover in Libyan Oil Companies & Dardar et. al (2012) \\
\hline Security & Chinese securities market & Ting (2011) \\
\hline $\begin{array}{l}\text { Social security } \\
\text { system }\end{array}$ & Labor turnover process & Schwerdt (2011) \\
\hline
\end{tabular}

\section{Methodology}

Laborturnover problem in seaport companies has become an issue of high priority and needs to be evaluated by analytical techniques. Therefore, the current study aims at defining the criteria involved in labor turnover and suggest alternative solutions. Due to complex nature of the problem, there are many criteria related to labor turnover. Such problems are successfully eliminated using Fuzyy MCDM techniques in literature (Özdemir and Güneroğlu, 2015; Güneroğlu et al. 2016; Özdemir, 2016). FuzzyDEMATEL and FuzzyTOPSIS techniques are suggested here to analyse the labor 
turnover problem of seaport companies. Inter relations among criteria and their weights were first determined and then alternative solutions were suggested. Subjectivity of expert groups was also eliminated by applying pairwise comparisons through an expert questionnaire.

\subsection{Fuzzy DEMATEL Technique}

DEMATEL technique is effective in determining inter relations among criteria involved in decision making process. It was first applied by Battelle Memorial Research Center between 1972 and 1976 (Chang et al. 2011; Bali et al, 2014). The technique is capable of evaluation the criteria on causal basis as well as separating effects groups ( $\mathrm{Li}$ and Tzeng, 2009). It is also helpful technique as it summarizes the cause and effect groups graphically. The most important feature of the technique that seperates it from other methodologies is the investigation of the interrelationships among criteria (Wu et al. 2007; Özdemir, 2016). DEMATEL has been applied in many scientific studies from various fields but Lotfi A. Zadeh (1965) was first applied the technique by combining it with the fuzzy logic (Wu and Lee, 2007; Yang et al., 2008; Shieh et al., 2010; Chang et al. 2011; Shahraki and Paghleh, 2011; Güneroğlu et al. 2016; Özdemir, 2016). More realistic results can be obtained by adding the fuzzy logics to the DEMATEL process, this is the appropriate way to eliminate the subjectivitiy and uncertainties in decision making process. FuzzyDEMATEL is explained as follow (Chang et al. 2011; Güneroğlu et al. 2016; Özdemir, 2016; Özdemir and Güneroğlu, 2017).

A membership function for the Fuzzy set $\tilde{A}$ can be represented by triangular fuzzy numbers as $(r, y, z)$ and written as,

$$
\mu \tilde{A}(x)=\left\{\begin{array}{lr}
0, & x<1 \\
\frac{x-r}{y-r}, & r \leq x \leq y \\
\frac{z-x}{z-y}, & y \leq x \leq z \\
0, & x>Z
\end{array}\right.
$$

Step 1. Defination of the criteria and deciding on Fuzzy Linguistic Scale:

The first step of the technique requires designing of the fuzzy linguistic scale that is necessary to convert pair wise comparison statements to triangular fuzzy numbers. The values shown in Table 2 can be used as a reference scale;

Table 2. Linguistic terms and corresponding linguistic values ( $\mathrm{Wu}$ and Lee, 2007; Chang et al. 2011; Bali et al. 2014; Özdemir, 2016).

\begin{tabular}{cc}
\hline Linguistic Terms & Linguistic Values \\
\hline No influence (0) & $(0 ; 0 ; 0.25)$ \\
Little influence (1) & $(0 ; 0,25 ; 0.50)$ \\
Low influence (2) & $(0.25 ; 0,50 ; 0.75)$ \\
High influence (3) & $(0,50 ; 0.75 ; 1)$ \\
Strongly influence (4) & $(0.75 ; 1 ; 1)$ \\
\hline
\end{tabular}

Step 2. In this step, direct-relation matrix is obtained by using pair wise comparisons provided by experts' evaluations. This (nxn) dimension matrix can be 
written as $\breve{K}=\breve{K}_{i j} \quad$ nxn where $\breve{K}_{i j}$ is the weight effect of the criterion " $i$ " on criterion “j”.

Step 3. The normalized fuzzy direct-relation matrix $\breve{A}=\breve{a}_{i j} \quad{ }_{n x n}$ is computed according to Eq. 1 and Eq. 2 in this step.

$$
\begin{aligned}
& \tilde{a}_{i j}=\frac{\breve{K}}{s}=\left(\frac{r_{i j}}{s}, \frac{y_{i j}}{s}, \frac{z_{i j}}{s}\right) \\
& s=\max _{1 \leq i \leq n}\left(\sum_{j=1}^{n} r_{i j}\right) s=\max _{1 \leq i \leq n}\left(\sum_{j=1}^{n} y_{i j}\right) s=\max _{1 \leq i \leq n}\left(\sum_{j=1}^{n} z_{i j}\right)
\end{aligned}
$$

Step 4. Fuzzy total-relation matrix is defined as " $\check{T}$ " and can be separated to three sub-matrices $\left(\mathrm{A}_{\mathrm{r}}, \mathrm{A}_{\mathrm{y}}, \mathrm{A}_{\mathrm{z}}\right)$ and written according to Eq.3 as follow, $\check{T}=\check{A}+\overline{A^{2}}+\overline{A^{3}}+\ldots=\sum_{i=1}^{\infty} \tilde{A}^{i}=\check{A}(I-\tilde{A})^{-1}$

Where " $I$ " an identity matrix and $\check{T}=\check{t}_{i j} \quad{ }_{n x n}$ is total-relation matrix , $\check{t}_{i j}=\left(\check{t}_{i j, r}, \check{t}_{i j, y}, \check{t}_{i j, z}\right)$ are the weights attributed by an expert for each criteria, this step is repeated for all sub-matrices separately and finally the results are combined in one matrix.

Step 5. Sending and receiving group criteria are defined in this step. Assuming, the sum of the row " $i$ " is $\widetilde{D}_{i}=\sum_{j=1}^{n} t_{i j}$ and sum of the column " $j$ " is $\widetilde{R}_{i}=\sum_{j=1}^{n} t_{i j}$. The component " $\widetilde{D}_{i}$ " is direct and indirect sending function of criterion " $i$ " on other criteria whereas " $\tilde{R}_{i}$ " is a receiving function. Therefore, $(\breve{D}+\check{R})$ is the impact level of criterion " $i$ " on both receiving and sending factors and $(\widetilde{D}-\breve{R})$ is the net effect of criterion " $i$ " on the decision network. The value of $(\breve{D}-\breve{R})$ is used to decide if the criterion is sending or receving considering the all involved criteria.

Step 6. Defuzzification proceses has to be applied in order to obtain practical absolute values of the decision problem. There are many defuzzification techniques in literature. In this study arithmetic mean is used as shown in Eq.4 and Eq.5.

$$
\begin{aligned}
& \left(\widetilde{D}_{i}+\widetilde{R}_{i}\right)=\frac{r+y+z}{3} \\
& \left(\widetilde{D}_{i}-\widetilde{R}_{i}\right)=\frac{r+y+z}{3}
\end{aligned}
$$

According to results of the defuzzification process, a theresheold value should be decided and used to choose which criteria will be included in the cause and effect diagram.

Step 7. The final step is on calculating the criteria weights normalized between $[0,1]$ by using Eq.6 and Eq.7.

$$
\begin{aligned}
& w_{i}=\sqrt{\left[\left(\widetilde{D}_{i}+\widetilde{R}_{i}\right)\right]^{2}+\left[\left(\widetilde{D}_{i}-\widetilde{R}_{i}\right)\right]^{2}} \\
& W_{i=\frac{w_{i}}{\sum_{i=1}^{n} w_{i}}}
\end{aligned}
$$

\subsection{Fuzzy TOPSIS Technique}


Fuzzy TOPSIS technique proposed by Chen (2000) was used in this study. There are many techniques in literature that suggest using of TOPSIS method (Chu, 2002; Yong, 2006; Kim et al., 2011; Ju and Wang, 2012; Li et al. 2014; Özdemir, 2016). In this study the Chen (2000) triangular fuzzy numbers based on vertex range scaling was used. This technique is widely used to ranking the alternatives of fuzzy decision making problems. Application of the technique was explained below (Chu and Lin, 2003; Yong, 2006; Özdemir, 2016).

Step 1. Normalization is applied in this step to scale all obtained fuzzy values between $[0,1]$ as shown in Eq. 8 and Eq.9.

$$
\begin{aligned}
& \widetilde{D}=\left[\widetilde{d_{\imath \jmath}}\right]_{\mathrm{mxn}} \quad \text { and } \quad \widetilde{d_{\imath \jmath}}=\left(\frac{a_{i j}}{c_{j}^{*}}, \frac{b_{i j}}{c_{j}^{*}}, \frac{c_{i j}}{c_{j}^{*}}\right) \\
& \widetilde{D}=\left[\widetilde{d_{l j}}\right]_{\mathrm{mxn}} \quad \text { and } \quad \widetilde{d_{\imath j}}=\left(\frac{a_{j}^{-}}{c_{i j}}, \frac{a_{j}^{-}}{b_{i j}}, \frac{a_{j}^{-}}{a_{i j}}\right)
\end{aligned}
$$

In Eq.8 and Eq.9, if " $j "$ is the benefit criterion, then $c_{j}^{*}=\max _{i} c_{i j}$; and if it is cost criterion then $a_{j}^{-}=\min _{i} a_{i j}$

Step 2. As a second step, Criteria weights and normalized fuzzy decision matrix is multiplyed to obtain the weighted fuzzy decision matrix as presented in Eq. 10 .

$$
\widetilde{K}=\left[\widetilde{k_{\imath \jmath}}\right]_{\mathrm{mxn}} i=1,2, \ldots, m \quad j=1,2, \ldots, n \quad \text { ise } \widetilde{k_{l \jmath}}=\widetilde{d_{\imath \jmath}} \cdot \widetilde{w_{l \jmath}}
$$

Step 3. This step involves calculating the distances, the distance from fuzzy positive ideal solution $\left(\mathrm{A}^{+}\right)$of each criterion is $\left(m_{i}^{+}\right)$and from fuzzy negative ideal solution $\left(\mathrm{A}^{-}\right)$is $\quad\left(m_{i}^{-}\right)$. Then, the positive and negative distances can be calculated as shown in Eq.11 and Eq.12.

$$
\begin{array}{ll}
m_{i}^{*}=\sum_{j=1}^{n} m\left(\widetilde{k_{\imath \jmath}}, \widetilde{k_{J}^{*}}\right) & i=1,2, \ldots, \mathrm{m} \\
m_{i}^{-}=\sum_{j=1}^{n} m\left(\widetilde{k_{\iota \jmath}}, \widetilde{k_{J}^{-}}\right) \quad i=1,2, \ldots, \mathrm{m}
\end{array}
$$

For the "benefit" criteria, $\mathrm{A}^{+}$and $\mathrm{A}^{-}$are calculated by applying Eq.13 and Eq.14

$\mathrm{A}^{+}=\left(k_{1}^{+}, k_{2}^{+}, \ldots, k_{n}^{+}\right)$and $k_{j}^{+}=(1,1,1)$, Eq.16

For the "cost" criteria " $\mathrm{A}^{+}$" ve " $A^{-"}$ are calculated as shown in Eq.15 and

$$
\begin{array}{ll}
\mathrm{A}^{+}=\left(k_{1}^{+}, k_{2}^{+}, \ldots, k_{n}^{+}\right) \text {and } & k_{j}^{+}=(0,0,0) \\
A^{-}=\left(k_{1}^{-}, k_{2}^{-}, \ldots, k_{n}^{-}\right) \text {and } & k_{j}^{-}=(1,1,1)
\end{array}
$$

Step 4. At this step, proximity coefficient is calculated. The calculation of the coefficient " $C C_{i}$ " is based on positive and negative distances among criteria and given in Eq. 17.

$C C_{i}=\frac{m_{i}^{-}}{m_{i}^{+}+m_{i}^{-}} ; \quad$ where $i=1,2, \ldots, \mathrm{m}$ 
Step 5. Finally, ranking of the alternatives is carried out according to calculated proximity coefficient beginning from the most effective one.

\section{Case Study}

Application of the case study was carried out in three sections. At first section, criteria, alternatives, fuzzy number type, related fuzzy scales and pairwise comparison matrix results were obtained. The second section involved with application of the proposed techniques and completion of calculations. Finally, results of the study were analysed and suggetions on labor turnover in seaport companies were made. Criteria were decided by reviewing the available literature on abor turnover problem. In order to determine the related criteria and alternatives, 190 workers (operation managers, oparators and workers) and 23 experts were interviewed. Criteria and alternatives used in the study were given in Table 3.

A digital questionnaire was designed in order to carry out the pairwise comparisons evaluations with corresponding expert groups. The expert group consisted of 17 persons from port management expertise and 8 persons from the academia which are focused on port management research area. Totally 25 experts' opnions were acquaired for detrmining the most effective criteria and sort out the possible alternatives for the labor turnover problem in seaport industry.

Table 3. Criteria and alternatives used in study

\begin{tabular}{|l|l|}
\hline \multicolumn{1}{|c|}{ Criterias } & Alternatives \\
\hline C1- Cancellation of labor contract & A1- Wage concession \\
\hline C2- Health problems & A2- Bonus pay \\
\hline C3- Un wellcomed managers & A3- Performance evaluations \\
\hline C4- Family problems & A4- Employee suggestion system \\
\hline C5- The lack of job security (guaranteed jobs) & A5- Taking incentives in work flow \\
\hline C6- Negative friendship with co-workers & A6- Carrier opportunities \\
\hline C7- Limited carrier opportunities & A7- Respect \\
\hline C8- Inadaptability of working environment & A8- Fare and contunious working environment \\
\hline C9- Low wages & A9- Offering partnership \\
\hline C10- Finding another job & A10- Being part of the decision process \\
\hline
\end{tabular}

Each expert was properly completed the pairwise comparison matrix using the linguistic scale. As a step forward, the verbal replies were converted to the triangular fuzzy numbers by previously determined linguistic scale given in Table 1 and Table 4. MCDM litearature was used to compile the necessary linguistic scales used in this study (Chen 2000; Chen, Torng Özdemir and Güneroğlu, 2017). Arithmetic mean was used to combine all matrices in to a single matrix. Then, normalized direct relation matrix $\bar{A}$ was calculated using Eq.1 and Eq.2.

Table 4. Linguistic terms and corresponding linguistic values for alternatives (Chen 2000; Chen, Torng and Huang 2005; Özdemir 2016; Özdemir and Güneroğlu 2016). 


\begin{tabular}{cc}
\hline Linguistic Terms & Fuzzy Numbers Values \\
\hline Very Low influence & $(0,0,3)$ \\
Low influence & $(0,2.5,5)$ \\
Medium influence & $(2.5,5,7.5)$ \\
High influence & $(5,7.5,10)$ \\
Very High influence & $(7,10,10)$ \\
\hline
\end{tabular}

Three separate matrices $\left(\tilde{A_{\mathrm{r}}}, \tilde{A} \mathrm{y}, \tilde{A} \mathrm{z}\right)$ were obtained from direct relation matrix and fuzzy relation matrix $\breve{T}$ was determined using Eq3. Defuzzification was applied using Eq. 4 and Eq.5. The weight of each criteria was calculated by applying Eq. 6 and Eq.7. Sending $(\breve{D}+\breve{R})$ and receiving groups $(\breve{D}-\breve{R})$ of the inner relations among involved criteria were defined as it is in Table 6. Cause and effect diagram of the solution system was also given in Fig.1. according to Fig. 1 effecting criteria are C2, $\mathrm{C} 8, \mathrm{C} 7, \mathrm{C} 5, \mathrm{C} 3$ and $\mathrm{C} 9$ and the others are affected criteria.

For ranking the previously decided alternatives based on expert evaluations Fuzzy TOPSIS technique by Chen (2000) was used. Decision matrix was obtained by applying Eq.18 and Eq.19 and Table 4 was used for conversion the linguistic results to triangular fuzzy numbers.

$\tilde{C}_{i j}=(1 / N) \otimes\left(\tilde{c}_{i j}^{1} \oplus \tilde{c}_{i j}^{2} \oplus \ldots \oplus \tilde{c}_{i j}^{N}\right)$

$\widetilde{D}_{i j}=(1 / N) \otimes\left(\tilde{d}_{i j}^{1} \oplus \tilde{d}_{i j}^{2} \oplus \ldots \oplus \tilde{d}_{i j}^{N}\right)$

Tablo 5. Normalized fuzzy direct-relation matrix $\bar{A}$ 
Ü. Özdemir 10/3 (2018) 33-52

\begin{tabular}{|c|c|c|c|c|c|c|c|c|c|c|}
\hline & C1 & $\mathrm{C} 2$ & $\mathrm{C} 3$ & $\mathrm{C} 4$ & C5 & C6 & C7 & C8 & C9 & $\mathrm{C} 10$ \\
\hline C1 & $(0 ; 0 ; 0)$ & $(0 ; 0 ; 0,25)$ & $\begin{array}{c}(0,20 ; 0,20 \\
; 0,18)\end{array}$ & $\begin{array}{c}(0,14 ; 0,15 \\
; 0,17)\end{array}$ & $\begin{array}{c}(0,20 ; 0,19 \\
; 0,17)\end{array}$ & $\begin{array}{l}(0.200 ; 0.4 \\
33 ; 0.633)\end{array}$ & $\begin{array}{c}(0,08 ; 0,13 \\
; 0,17)\end{array}$ & $\begin{array}{c}(0,06 ; 0,09 \\
; 0,12)\end{array}$ & $\begin{array}{c}(0,14 ; 0,18 \\
; 0,23)\end{array}$ & $\begin{array}{c}(0 ; 0,04 ; 0 \\
08)\end{array}$ \\
\hline $\mathrm{C} 2$ & $\begin{array}{l}(0,06 ; 0,11 \\
; 0,12)\end{array}$ & $(0 ; 0 ; 0)$ & $\begin{array}{c}(0,03 ; 0,08 \\
; 0,12)\end{array}$ & $\begin{array}{c}(0,03 ; 0,08 \\
; 0,11)\end{array}$ & $\begin{array}{c}(0,09 ; 0,09 \\
; 0,12)\end{array}$ & $\begin{array}{c}(0,06 ; 0,09 \\
; 0,12)\end{array}$ & $\begin{array}{c}(0,17 ; 0,17 \\
; 0,16)\end{array}$ & $\begin{array}{c}(0,00 ; 0,09 \\
; 0,15)\end{array}$ & $\begin{array}{c}(0,14 ; 0,18 \\
; 0,23)\end{array}$ & $\begin{array}{c}(0,06 ; 0,01 \\
1 ; 0,14)\end{array}$ \\
\hline C3 & $\begin{array}{c}(0,20 ; 0,19 \\
; 0,18)\end{array}$ & $\begin{array}{c}(0,20 ; 0,19 \\
; 0,17)\end{array}$ & $(0 ; 0 ; 0)$ & $\begin{array}{c}(0,11 ; 0,16 \\
; 0.19)\end{array}$ & $(0 ; 0 ; 0,06)$ & $\begin{array}{c}(0,13 ; 0,17 \\
; 0,19)\end{array}$ & $\begin{array}{c}(0,26 ; 0.5 \\
0.73)\end{array}$ & $\begin{array}{c}(0 ; 0,15 ; 0 \\
35)\end{array}$ & $\begin{array}{c}(0 ; 0,06 ; 0 \\
09)\end{array}$ & $\begin{array}{c}(0,17 ; 0,17 \\
; 0,16)\end{array}$ \\
\hline $\mathrm{C} 4$ & $\begin{array}{c}(0,09 ; 0,09 \\
; 0,12)\end{array}$ & $\begin{array}{c}(0,17 ; 0,17 \\
; 0,18)\end{array}$ & $\begin{array}{c}(0,09 ; 0,09 \\
; 0,12)\end{array}$ & $(0 ; 0 ; 0)$ & $\begin{array}{c}(0,09 ; 0,09 \\
; 0,14)\end{array}$ & $(0 ; 0,0,05)$ & $\begin{array}{c}(0 ; 0.20 ; 0 . \\
40)\end{array}$ & $\begin{array}{c}(0,20 ; 0,19 \\
; 0,18)\end{array}$ & $\begin{array}{c}(0,20 ; 0,19 \\
; 0,17)\end{array}$ & $\begin{array}{c}(0,09 ; 0,11 \\
; 0,14)\end{array}$ \\
\hline C5 & $\begin{array}{c}(0,20 ; 0,23 \\
; 0,17)\end{array}$ & $\begin{array}{c}(0,24 ; 0,20 \\
; 0,18)\end{array}$ & $\begin{array}{c}(0,14 ; 0,19 \\
; 0,20)\end{array}$ & $\begin{array}{c}(0,23 ; 0,21 \\
; 0,18)\end{array}$ & $(0 ; 0 ; 0)$ & $\begin{array}{c}(0,11 ; 0,16 \\
; 0.19)\end{array}$ & $\begin{array}{c}(0,20 ; 0,19 \\
; 0,17)\end{array}$ & $(0 ; 0 ; 0,5)$ & $\begin{array}{c}(0 ; 0,06 ; 0 \\
09)\end{array}$ & $\begin{array}{c}(0,03 ; 0,08 \\
; 0,11)\end{array}$ \\
\hline C6 & $\begin{array}{c}(0,26 ; 0,23 \\
; 0,18)\end{array}$ & $\begin{array}{c}(0,06 ; 0,12 \\
; 0,17)\end{array}$ & $\begin{array}{c}(0,23 ; 0,21 \\
; 0,18)\end{array}$ & $\begin{array}{c}(0,24 ; 0,20 \\
; 0,18)\end{array}$ & $\begin{array}{c}(0,20 ; 0,19 \\
; 0,17)\end{array}$ & $(0 ; 0 ; 0)$ & $\begin{array}{c}(0 ; 0,06 ; 0 \\
09)\end{array}$ & $\begin{array}{c}(0 ; 0,20 ; 0 \\
40)\end{array}$ & $\begin{array}{c}(0,08 ; 0,13 \\
; 0.16)\end{array}$ & $\begin{array}{c}(0 ; 0,04 ; 0 \\
08)\end{array}$ \\
\hline C7 & $\begin{array}{c}(0,00 ; 0,00 \\
; 0,25)\end{array}$ & $\begin{array}{c}(0,06 ; 0,11 \\
; 0,14)\end{array}$ & $\begin{array}{c}(0,09 ; 0,11 \\
; 0,14)\end{array}$ & $\begin{array}{c}(0 ; 0,100 ; 0 \\
, 300)\end{array}$ & $(0 ; 0 ; 0,0,6)$ & $\begin{array}{c}(0,09 ; 0,09 \\
; 0,14)\end{array}$ & $(0 ; 0 ; 0)$ & $\begin{array}{c}(0 ; 0,06 ; 0 \\
11)\end{array}$ & $\begin{array}{c}(0,13 ; 0,17 \\
; 0.19)\end{array}$ & $\begin{array}{c}(0 ; 0,06 ; 0 \\
09)\end{array}$ \\
\hline C8 & $\begin{array}{c}(0,00 ; 0,25 \\
; 0,50)\end{array}$ & $\begin{array}{c}(0,14 ; 0,15 \\
; 0,17)\end{array}$ & $\begin{array}{c}(0,20 ; 0,19 \\
; 0,17)\end{array}$ & $\begin{array}{c}(0,20 ; 0,19 \\
; 0,17)\end{array}$ & $\begin{array}{c}(0,23 ; 0,21 \\
; 0,18)\end{array}$ & $\begin{array}{c}(0,03 ; 0,08 \\
; 0,11)\end{array}$ & $(0 ; 0 ; 0,5)$ & $(0 ; 0 ; 0)$ & $\begin{array}{c}(0,1 ; 0,21 ; \\
0.41)\end{array}$ & $\begin{array}{c}(0,09 ; 0,14 \\
, 0,17)\end{array}$ \\
\hline C9 & $\begin{array}{c}(0,09 ; 0,09 \\
; 0,12)\end{array}$ & $\begin{array}{c}(0 ; 0,06 ; 0, \\
11)\end{array}$ & $\begin{array}{c}(0 ; 0,06 ; 0 \\
11)\end{array}$ & $\begin{array}{c}(0,06 ; 0,09 \\
; 0,12)\end{array}$ & $\begin{array}{c}(0,14 ; 0,19 \\
; 0,20)\end{array}$ & $\begin{array}{c}(0,10 ; 0,15 \\
; 0.18)\end{array}$ & $\begin{array}{c}(0,09 ; 0,09 \\
; 0,14)\end{array}$ & $\begin{array}{c}(0,09 ; 0,09 \\
; 0,14)\end{array}$ & $(0 ; 0 ; 0)$ & $\begin{array}{c}(0 ; 0,04 ; 0 \\
08)\end{array}$ \\
\hline C10 & $\begin{array}{c}(0.10,0.15 \\
, 0.18)\end{array}$ & $\begin{array}{c}(0,17 ; 0,17 \\
; 0,16)\end{array}$ & $\begin{array}{c}(0,09 ; 0,09 \\
; 0,12)\end{array}$ & $\begin{array}{c}(0,17 ; 0,17 \\
; 0,16)\end{array}$ & $\begin{array}{c}(0 ; 0,04 ; 0 \\
08)\end{array}$ & $(0 ; 0 ; 0,05)$ & $\begin{array}{c}(0 ; 0,06 ; 0 \\
11)\end{array}$ & $\begin{array}{c}(0,23 ; 0,21 \\
; 0,18)\end{array}$ & $\begin{array}{c}(0,03 ; 0,08 \\
; 0,11)\end{array}$ & $(0 ; 0 ; 0)$ \\
\hline
\end{tabular}


Table 6. D and R values

\begin{tabular}{|c|c|c|c|c|c|}
\hline & $\breve{D}+\breve{R}$ & $\breve{D}-\widetilde{R}$ & $\left.\widetilde{D}_{i}+\widetilde{\boldsymbol{R}}_{\boldsymbol{i}}\right)^{\mathrm{Def}}$ & $\left(\widetilde{\boldsymbol{D}}_{\boldsymbol{i}}-\widetilde{\boldsymbol{R}}_{\boldsymbol{i}}\right)^{\mathrm{Def}}$ & $w_{i}$ \\
\hline C1 & $(6,42 ; 8,34 ; 10,43)$ & $(-1,13 ;-0,77 ;-0,59)$ & 8,32 & $-0,87$ & 0,0896 \\
\hline $\mathrm{C} 2$ & $(4,32 ; 6,07 ; 10,34)$ & $(0,92 ; 1,1 ;-0,13)$ & 6.71 & 1,87 & 0,0936 \\
\hline $\mathrm{C3}$ & $(9,24 ; 10,58 ; 11,12)$ & $(0,17 ; 0,34 ;-0,38)$ & 10,11 & 0,03 & 0,0996 \\
\hline $\mathrm{C} 4$ & $(7,40 ; 9,04 ; 12,30)$ & $(-1,76 ;-1,56 ;-1,16)$ & 9,38 & $-1,51$ & 0,0796 \\
\hline C5 & $(9,00 ; 10,30 ; 14,44)$ & $(0,62 ; 0,83 ; 0,94)$ & 11,04 & 0,81 & 0,1126 \\
\hline C6 & $(6,75 ; 9,34 ; 13,27)$ & $(-1,13 ;-0,77 ;-0,59)$ & 9,58 & $-0,85$ & 0,1016 \\
\hline C7 & $(6,69 ; 9,11,14,18)$ & $(0,88 ; 1,25 ; 1,84)$ & 9,73 & 1,34 & 0,1056 \\
\hline C8 & $(3,20 ; 6,88 ; 12,28)$ & $(1,34 ; 1,75 ; 1,82)$ & 7,25 & 1,65 & 0,1036 \\
\hline C9 & $(11,30 ; 12,64 ; 15,78)$ & $(0,35 ; 0,44 ; 0,97)$ & 13,12 & 0,58 & 0,1186 \\
\hline $\mathrm{C} 10$ & $(7,25 ; 9,87,14,23)$ & $(-1,31 ;-0,42 ;-0,18)$ & 10,13 & $-0,83$ & 0,0956 \\
\hline$\sum w c i$ & - & - & - & - & 1 \\
\hline
\end{tabular}

As a next step, Eq.8 and Eq.9 was used to scale the results between $[0,1]$ the normalized results were given in Table 7 .

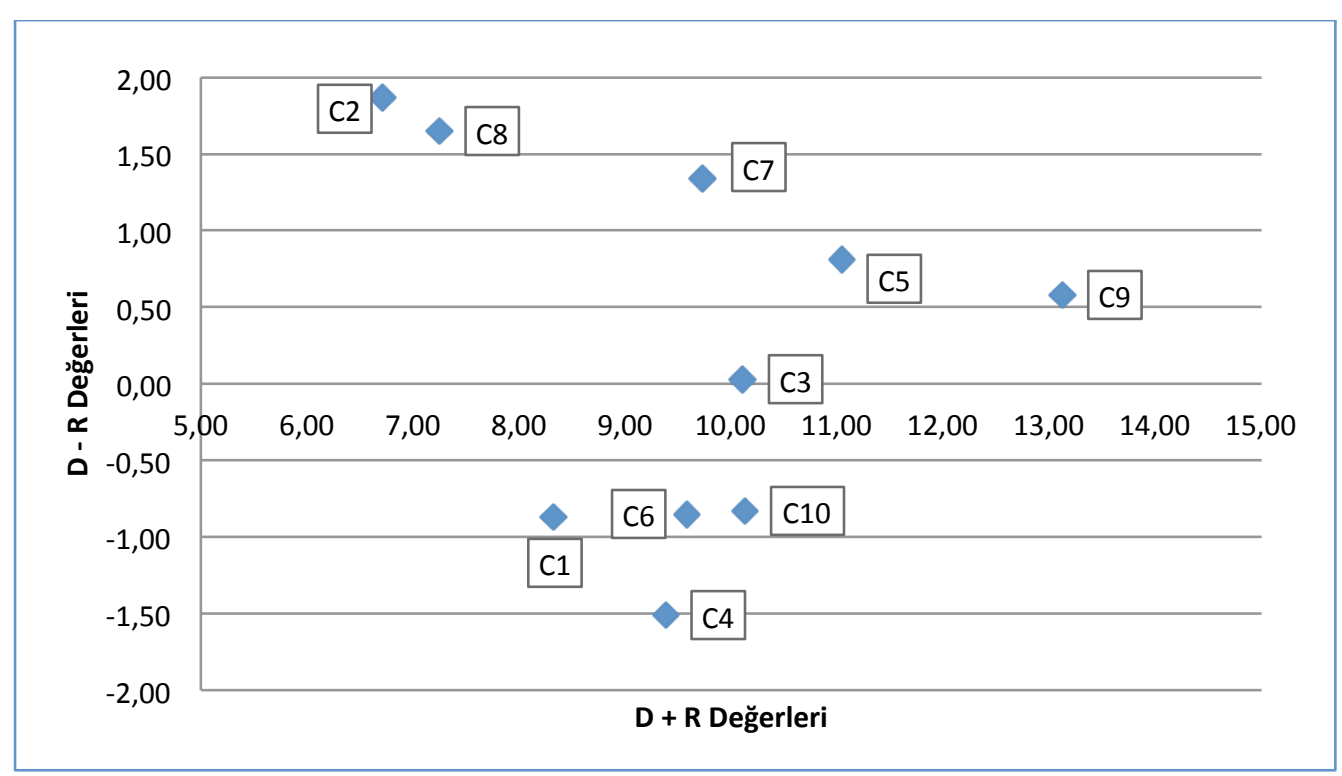

Figure 1. Cause - Effect graphical diagram 
In order to obtain fuzzy decison matrix, criteria weight shown in Table 6 was multiplied by normalized fuzzy decision matrix using Eq.10.

Table 7. Normalized fuzzy decision matrix

\begin{tabular}{|l|c|c|c|c|c|c|c|c|c|c|c|c|c|c|c|}
\hline & \multicolumn{3}{|c|}{ A6 } & \multicolumn{3}{|c|}{ A7 } & \multicolumn{3}{c|}{ A8 } & \multicolumn{3}{c|}{ A9 } & \multicolumn{3}{c|}{ A10 } \\
\hline C1 & 0,045 & 0,075 & 0,092 & 0,078 & 0,123 & 0,185 & 0,025 & 0,054 & 0,078 & 0,008 & 0,047 & 0,214 & 0,080 & 0,095 & 0,142 \\
\hline C2 & 0,123 & 0,174 & 0,325 & 0,052 & 0,084 & 0,107 & 0,105 & 0,133 & 0,184 & 0,062 & 0,147 & 0,185 & 0,251 & 0,325 & 0,412 \\
\hline C3 & 0,074 & 0,099 & 0,241 & 0,124 & 0,147 & 0,240 & 0,044 & 0,482 & 0,487 & 0,254 & 0,270 & 0,304 & 0,015 & 0,080 & 0,105 \\
\hline C4 & 0,284 & 0,308 & 0,412 & 0,047 & 0,087 & 0,095 & 0,062 & 0,080 & 0,110 & 0,071 & 0,181 & 0,200 & 0,048 & 0,095 & 0,152 \\
\hline C5 & 0,017 & 0,078 & 0,129 & 0,103 & 0,141 & 0,189 & 0,085 & 0,162 & 0,263 & 0,214 & 0,250 & 0,309 & 0,111 & 0,283 & 0,312 \\
\hline C6 & 0,267 & 0,307 & 0,521 & 0,058 & 0,061 & 0,125 & 0,147 & 0,150 & 0,191 & 0,100 & 0,243 & 0,272 & 0,169 & 0,205 & 0,325 \\
\hline C7 & 0,324 & 0,385 & 0,411 & 0,103 & 0,184 & 0,200 & 0,153 & 0,211 & 0,247 & 0,114 & 0,231 & 0,285 & 0,062 & 0,108 & 0,188 \\
\hline C8 & 0,240 & 0,361 & 0,475 & 0,040 & 0,057 & 0,084 & 0,149 & 0,157 & 0,183 & 0,042 & 0,058 & 0,140 & 0,172 & 0,263 & 0,300 \\
\hline C9 & 0,043 & 0,065 & 0,414 & 0,142 & 0,171 & 0,200 & 0,014 & 0,080 & 0,120 & 0,153 & 0,241 & 0,250 & 0,140 & 0,254 & 0,303 \\
\hline C10 & 0,173 & 0,240 & 0,284 & 0,210 & 0,014 & 0,012 & 0,085 & 0,141 & 0,168 & 0,160 & 0,256 & 0,316 & 0,020 & 0,069 & 0,104 \\
\hline
\end{tabular}

\begin{tabular}{|l|c|c|c|c|c|c|c|c|c|c|c|c|c|c|c|}
\hline & \multicolumn{3}{|c|}{ A1 } & \multicolumn{3}{|c|}{ A2 } & \multicolumn{4}{c|}{ A3 } & \multicolumn{3}{c|}{ A4 } & \multicolumn{3}{c|}{ A5 } \\
\hline C1 & 0,302 & 0,317 & 0,703 & 0,354 & 0,477 & 0,489 & 0,324 & 0,541 & 0,603 & 0,071 & 0,374 & 0,475 & 0,078 & 0,127 & 0,234 \\
\hline C2 & 0,520 & 0,621 & 0,742 & 0,308 & 0,517 & 0,627 & 0,184 & 0,574 & 0,698 & 0,058 & 0,247 & 0,412 & 0,124 & 0,178 & 0,347 \\
\hline C3 & 0,230 & 0,244 & 0,341 & 0,521 & 0,557 & 0,639 & 0,258 & 0,325 & 0,714 & 0,035 & 0,041 & 0,087 & 0,047 & 0,078 & 0,247 \\
\hline C4 & 0,725 & 0,854 & 0,903 & 0,735 & 0,742 & 0,839 & 0,365 & 0,634 & 0,821 & 0,067 & 0,148 & 0,472 & 0,257 & 0,387 & 0,412 \\
\hline C5 & 0,304 & 0,402 & 0,508 & 0,357 & 0,621 & 0,841 & 0,174 & 0,189 & 0,478 & 0,064 & 0,148 & 0,354 & 0,017 & 0,092 & 0,124 \\
\hline C6 & 0,533 & 0,632 & 0,714 & 0,547 & 0,617 & 0,624 & 0,254 & 0,273 & 0,514 & 0,048 & 0,517 & 0,568 & 0,051 & 0,068 & 0,098 \\
\hline C7 & 0,415 & 0,620 & 0,687 & 0,452 & 0,492 & 0,812 & 0,078 & 0,325 & 0,387 & 0,347 & 0,478 & 0,604 & 0,247 & 0,308 & 0,374 \\
\hline C8 & 0,238 & 0,384 & 0,472 & 0,245 & 0,337 & 0,456 & 0,067 & 0,147 & 0,325 & 0,074 & 0,471 & 0,578 & 0,368 & 0,385 & 0,493 \\
\hline C9 & 0,215 & 0,305 & 0,514 & 0,278 & 0,452 & 0,478 & 0,047 & 0,298 & 0,478 & 0,038 & 0,063 & 0,478 & 0,219 & 0,381 & 0,411 \\
\hline
\end{tabular}

Following the technique by Chen (2000) distances from the positive $\left(m_{i}^{*}\right)$ and negative $\left(m_{i}^{-}\right)$ideal solutions were determined by applying Eq. 11, 12, 13, 14, 15 and 16. Calculated distances were shown in Table 8 and 9 . The similartiy rate between each alternative and the ideal solution for both positive and negative solutions was calculated by means of Eq.17 and given in Table 10. 
Table 8. Total distance from each alternative A *

\begin{tabular}{|l|c|}
\hline \multicolumn{1}{|c|}{ Alternatives } & Total Distance \\
\hline A1 & 6,402 \\
\hline A2 & 6,384 \\
\hline A3 & 6,341 \\
\hline A4 & 6,412 \\
\hline A5 & 6,418 \\
\hline A6 & 6,457 \\
\hline A7 & 6,389 \\
\hline A8 & 6,420 \\
\hline A9 & 6,380 \\
\hline A10 & 6,442 \\
\hline
\end{tabular}

Table 9. Total distance from each alternative A -

\begin{tabular}{|l|c|}
\hline \multicolumn{1}{|c|}{ Alternatives } & Total Distance \\
\hline A1 & 4,520 \\
\hline A2 & 4,488 \\
\hline A3 & 4,789 \\
\hline A4 & 4,963 \\
\hline A5 & 4,338 \\
\hline A6 & 4,639 \\
\hline A7 & 4,843 \\
\hline A8 & 4,562 \\
\hline A9 & 4,660 \\
\hline A10 & 4,544 \\
\hline
\end{tabular}


Table 10. Proximity of each alternative to ideal solution

\begin{tabular}{|l|c|}
\hline \multicolumn{1}{|c|}{ Alternatives } & Total Distance \\
\hline A1 (1) & 0,476 \\
\hline A2 (2) & 0,470 \\
\hline A3 & 0,445 \\
\hline A4 & 0,430 \\
\hline A5 (5) & 0,458 \\
\hline A6 (3) & 0,465 \\
\hline A7 & 0,454 \\
\hline A8 & 0,450 \\
\hline A9 (4) & 0,462 \\
\hline A10 & 0,455 \\
\hline
\end{tabular}

\section{Results}

Ensuring continuous and high quality service level is the major aim of the any commercial company. Labour turnover rate is one of the key factors in establisihing longterm quality standarts and needs to be preciesly handled by the managers. Companies could be benefited from low labor turnover numbers whereas high rates can adversely affect the overall productivity of a company both direct and indirect manner.

Maritime sector is a labor intensive commerce that requires human resources from different specialization areas for working in ship and cargo operations. It is clear that human factor is the most influential factor in improving of port efficiency. High standart and qualified human resources are necessary for carrying out the port operations. The current study is focused on determining the factors that lead to labor turnover in maritime companies. Criteria that were considered effective in seaport labor turnover problem and alternatives for the possible solutions were analysed. According to findings of the current study the major criteria causing labor turnover in seaports can be stated according to their importance or weights as follow, low wages (C9), the lack of job security (guaranteed jobs) (C5), limited carrier opportunities (C7), inadaptability of working environment (C8), negative friendship with co-workers (C6), un wellcomed managers $(\mathrm{C} 3)$, finding another job $(\mathrm{C} 10)$, health problems $(\mathrm{C} 2)$, cancellation of labor contract $(\mathrm{C} 1)$ and family problems $(\mathrm{C} 4)$. From the criteria stated, C7, C5, C10 and C9 were determined as causing factors whereas the others were affected by the labor turnover problem.

The possible solutions for the labor tunover problem in seaports were defined as higher wages (A1), bonus pay (A2), carrier opportunities (A6), offering partnership (A9), taking incentives in work flow (A5) being part of the decision process (A10), respect (A7), fare and contunious working environment (A8), performance evaluations (A3) and employee suggestion system (A4). Considering the participant profile of the questionaires (190 persons), $6 \%$ was women and $94 \%$ was men. $86 \%$ of total participants were married. The age range was between 20 and 60 years old. $59 \%$ of the 
sampled profile were graduated from high schools whereas $16 \%$ of the total holded a university degree. $14 \%$ of the total participants worked more than 15 years in seaport companies and $21 \%$ was less than 5 years. The rate of 15 years working time within same company was no more than $17 \%$ and $42 \%$ of total participant worked between 5 10 years in the same company.

\section{Discussion and Recommendations}

The results of the study revealed that low wages are placed in the first category regarding job quiting in seaport companies. This might be attributed to the education level of the seaport workers who mainly do not have high grade education and considered as ordinary workers. The second factor that is effective in stopping working or leaving from the company was determined as the lack of job security or guaranteed jobs. The process of privatization in port sector has introduced a contract-based job model, which is mainly; depend on the performance of the workers or the financial efficiency of the port company, which is the main personal hiring methodology today in seaports (Özdemir, 2016). Therefore, it becomes a stressfull issue working without long term job guarantee and it may cause job qutiing in sepaorts as soon as finding an alternative better working system in other sectors or companies. Similar results by Nikbin et al. (2012), Rafiei et al. (2013), Pierce and Aguinis (2013), Slatten et al. (2011) are reported from other sectors that long term jobs and definite working conditions are very effective in labor turnover. The third important criterion noticed in this work regarding labor turnover problem is limited carrier opportunities, which limits to see light for future life in the eyes of port workers. The lack of carrier developments leads to workers to think pessimistic for the port industry and create a tendency to look for some alternatives for better working conditions. Private port companies should somehow develop attractive working models that at least ensure the near future job security of the workers based on their personal performance criteria is they care about the labor turnover problem in the sector. Because job security issue became an issue of high priorty as reported by Yilmaz and Halıc1 (2010).

In order to keep labor turnover in seaports at acceptable limits, it is recommended that two main factors "job guarantee" and "wage policy" should be arranged and managed in such a system that promotes the satisfaction of the workers as well as uncompromising the economic profit and efficiency of the company. It should be not forgotten that labor policy could be make unexpected major influences on the longterm business plans of the seaport investors. Therefore, motivation of the workers must be kept high by using some performance bonus system and applying special personal management policy that accounts for needs and sentiments of the workers. Better working conditions will definitely create higher productive working environment among workers and will develop their personal respects to their jobs.

Many studies reported that low rates of laborturnover could positively affect the productivity of the company (Steers and Mowday, 1981; Krackhardt and Porter, 1985; Guimaraes and Igbaria, 1992; Cheng and Brown, 1998; Dale-Olsen, 2006).

Labortunover is also an important issue in port management companies which has its own risks as a harsh working environment (Yalçın, 2005; Danacı and Kişi, 2014; Özdemir, 2016). Therfore, to avoid any working casualties the labour of the seaport companies should be highly qualiefied and trained persons with special enthusiasm to follow highly difficult working conditions. High safety standarts are also necessary in 
port operations as the major factor of seaport accidents is the human factor (Tatar et al., 2015; Özdemir, 2016). Therefore, determining laborturnover conditions is a complementary action to define the working standarts in seaport companies.

The global need for labour force has been rising in maritime sector. Beside that preparing a newcomer to be ready for working in seaport operations require time, intensive efforts and money that are met by the companies. Therefore, companies have a tendency toward hiring experienced workers. Obligatory training in seaports are limited with safety, security and health of the workers but the real experience is gathered during the carrying out a real port cargo operation. There are diverse work types involved in port operations. For example, recent developments in technological infrastructure have urged the companies to concentarate on specialists that are good at electronical operations. Automatisation of port handling equipments has changed the type of workers toward more qualified persons as well as causing reduction in total hired workers number.

Finally, labor turnover problem in seaport companies is investigated by using a hybrid decision making approach to find out the main causes and their associated alternatives that can be used for longterm efficiency of personal policy in the sector. It is belived that, the maritime sector could benefit from the quantitative evaluations presented in the current study, which is kept as simple as possible to be understood and applied by all stakeholders involved in the sector. The proposed methodology can be also applied to some other major problems of the maritime sector due to its simplicity and quantification capability.

\section{References}

Arocas, L. R., Camps, J. (2008), “A Model of High Performance Work Practices and Turnover", Intentions, Vol. 37, No1, 112-128.

Bali, Ö., Tutun, S., Pala, A. and Çörekçi, C. (2014), “A Mcdm Approach with Fuzzy Dematel and Fuzzy Topsis for 3 PL Provider Selection" Journal of Engineering and Natural Sciences, Vol. 32, 222-239.

Baysal, A.C. (1984), "İsletmelerde İşgücü Devri Sorunu”, Erciyes Üniversitesi İ̈B.F. Dergisi, Vol. 2, No. 6, 81-95 (in Turkish).

Blau, G., Boal, K. (1987), "Conceptualizing how job involvement and organizational commitment affect turnover and absenteeism", Academy of Management Review, Vol, 12, 288-300.

Bruzzone, A.G., Longo, F., Nicoletti, L. and Diaz, R. (2011), "Virtual Simulation for traininginports environments", Proceedings of the Summer Computer Simulation Conference, The Hague, Netherlands, 235-242.

Centeno, M. and Novo, A.A. (2012), "Excess worker turnover and fixed-term contracts: Causal evidence in a two-tier system", Labour Economics, Vol. 19, No.3, 320328.

Chang, B., Chang, W.C. and Wu, C.H. (2011), "Fuzzy DEMATEL Method for Developing Supplier Selection Criteria", Expert Systems with Applications, Vol. 38, No.3, 1850-1858. 
Chen, C.T. (2000), "Extensions of The Topsis for Group Decision-Making Under Fuzzy Environment", Fuzzy Sets and Systems, Vol. 114, No.1, 1-9.

Cheng, A. and Brown, A. (1998), "HRM strategies and labour tur $\neg$ nover in the hotel industry: a comparative study of Australia and Singapore", The International Journal of Human Resource Management, Vol. 9, No. 1, 136-154.

Chou, C.C. (2007), “A fuzzy MCDM Method for solving marine transshipment container port selection problems", Applied Mathematics and Computation, Vol. $186,435-444$.

Chu, T. (2002), "Selecting plant location via a fuzzy TOPSIS approach", International Journal of Advanced Manufacturing Technology, Vol. 20, No. 11, 859-864.

Chu, T.C. and Lin, Y.C. (2003), "A Fuzzy TOPSIS Method for Robot Selection" International Journal of Advanced Manufacturing Technology, Vol. 21, 284290.

Croasdell, D.T. (2001), "It's Role in Organizational Memory and Learning", Information System Management, Vol. 2, 811.

Çakar, D.N. and Ceylan, A. (2005), "İş Motivasyonunun Çalışan Bağl1lığ1 ve İşten Ayrılma Eğilimi Üzerindeki Etkileri”, Doğuş Üniversitesi Dergisi, Vol. 6, No.1, 52-66 (in Turkish).

Dale-Olsen, H. (2006), "Wages, fringe benefits and worker turnover", Labour Economics, Vol. 13, 87-105.

Danac1, A. and Kişi, H. (2014), "Limanlarda İş Güvenliği Uygulamaları", 8. Kıyı Mühendsliği Sempozyumu, 7-9 kasım 2014, İstanbul (in Turkish).

Dardar, A.H.A., Jusoh, A. and Rasli, A. (2012), “The Impact of Job Training, job satisfaction and Alternative Job Opportunities on Job Turnover in Libyan Oil Companies", Procedia - Social and Behavioral Sciences, Vol. 40, 389-394.

Demir, M. (2002), "Konaklama İsletmelerinde İnsan Kaynakları Kapsamında İsgücü Devir Hızının Analizi; Muğla Bölgesi Örneği”, Msc Thesis, University of Dokuz Eylül, Social Sciences Institute, İzmir, Turkey (in Turkish).

Esmer, S. (2010), "Konteyner Terminallerinde Lojistik Süreçlerin Optimizasyonu ve Bir Simülasyon Modeli”, Dokuz Eylül Üniversitesi Denizcilik Fakültesi, Dokuz Eylül Yayınları (in Turkish).

Gambardella, L.M., Mastrolilli, M., Rizzoli, A.E. and Zaffalon, M. (2001), "An optimization methodology for intermodal terminal management.", Journal of Intelligent Manufacturing, Vol. 12, No.5, 521-534.

Guimaraes, T., and Igbaria, M. (1992), "The determinants of turnover intentions: Comparing IC and IS personnel”, Information Systems Research, Vol. 3, No. 3, 73-303.

Güneroğlu N., Özdemir Ü. and Güneroğlu A. (2016), "Decisions on Quality Assurance Criteria of Recreational Beaches", Proceedings Of The Institution Of Civil Engineers- Municipal Engineer, Vol. 21: 1-10. 
Hanusheka, A.E., Rivkinb, G.S. and, Schiman, C.J. (2016), "Dynamic effects of teacher turnover on the quality of instruction", Economics of Education Review, Vol. 55:132-148.

Igbaria, M. and Guimaraes, T. (1999), "Exploring Differences in Employee Turnover Intentions and its Determinants Among Telecommuters and Non Telecommuters", Journal of Management Information Systems; JMIS, Vol 16, No.1, 147-164.

Jaros, S.J. (1995), “An assessment of Meyer and Ailen's (1991) three-component model of organizational commitment and turnover intentions", Academy of Management Journal, Vol. Best Papers Proceedings: 317-321.

Jiang, L., J., Chew, E., P., Lee, L., H. and Sun, Z. (2012), "DEA Based on Strongly Efficient and Inefficient Frontiers and its Application on Port Efficiency Measurement", OR Spectrum, Vol. 34, No. 4, 943-969.

Jung, S.H. and Yoon, H.H. (2014), “Antecedents and consequences of employees' job stress in a foodservice industry: Focused on emotional labor and turnover intent", International Journal of Hospitality Management, Vol. 38: 84-88.

Kazemian, H. B. (2002), “Fuzzy Logic Applications”, Expert Systems, 19(4):128-136.

Kim, S., Lee, K., Cho, J. K., and Kim, C.O. (2011), "Agent-based diffusion model for an automobile market with fuzzy TOPSIS-based product adoption process", Expert Systems with Applications, Vol. 38 No.6, 7270-7276.

Kim, Y., Jeong, J. and Ko, H.M. (2013), "A qualitative study of Korean music therapist's turnover experiences", The Arts in Psychotherapy, Vol. 40, No.5, 449-457.

Kovner, T.C., Djukic, M., Fatehi, K.F., Fletcher, J., Jun, J., Brewer, C. and Chacko, T. (2016), Estimating and preventing hospital internal turnover of newly licensed nurses: A Panel Survey", International Journal of Nursing Studies, Vol. 60, $251-262$.

Krackhardt, D. and Porter, L.W. (1985), "When friends leave a structural analysis of the relationship between turnover and stayers attitudes", Administrative Science Quarterly, Vol. 30, No.2, 242-285.

Kruzich, M.J., Mienko, A.J. and, Courtney, E.M. (2014), "Individual and work group influences on turnover intention among public child welfare workers: The effects of work group psychological safety", Children and Youth Services Review, Vol. 42, 20-27.

Lapointea, E. and Vandenberghe, C. (2017), "Supervisory mentoring and employee affective commitment and turnover: The critical role of contextual factors", Journal of Vocational Behavior, Vol. 98: 98-107.

Lannooa, S. and Verhofstadt, E. (2016), "What drives the drivers? Predicting turnover intentions in the Belgian Bus and coach industry", Transportation Research Part A: Policy and Practice, Vol. 91, 251-259.

Li, W.C. and Tzeng, G.H. (2009), "Identification of a threshold value for the DEMATEL method using the maximummean de-entropy algorithm to find 
critical services provided by a semiconductorintellectual property mall”, Expert Systems with Applications, Vol. 36, No.6, 9891-9898.

Li, M., Jin, L. and Wang, J. (2014), “A new MCDM method combining QFD with TOPSIS for knowledge management system selection from the user's perspective in intuitionistic fuzzy environment", Applied Soft Computing, Vol. $21,28-37$.

Lia, J., Kimb, G.W. and, Zhao, X. (2017), "Multilevel model of management support and casino employee turnover intention", Tourism Management, Vol. 59:193204.

Liang, G. S. (1999), "Fuzzy MCDM Based on Ideal and Anti-Ideal Concepts", EuropeanJournal of Operational Research, Vol. 112: 682-691.

Llacer, F.J.M. (2006), "Port privatization in Panama", Marine Policy,Vol. 30, No.5, 483-495.

Longo, F., Chiurco, A., Musmanno, R. and Nicoletti, L. (2015), "Operative and procedural cooperative training in marine ports", Journal of Computational Science, Vol. 10, 97- 107.

Mucuk, İ. (1998), “Modern İsletmecilik”, Türkmen Kitabevi, 9. Basım, İstanbul, 406.

Nikbin, D., Ismail, I., Marimuthu, M. and Armesh, H. (2012), "Perceived justice in service recovery and switching intention: Evidence from Malaysian mobiletelecommunication industry", Management Research Review, Vol. 35, No.3, 309-325.

Oral, E.Z., Kişi, H., Cerit, A.G., Tuna, O. and Esmer, S. (2007), "Port Governance In Turkey", Devolution, Port Governance and Port Performance. Editors: Mary R. Brooks and Kevin Cullinane, ISBN: 978-0-7623-1197-2, Elseiver: pp.171-184.

Özdemir, Ü. and Güneroğlu A. (2015), "Strategic Approach Model for Investigating The Cause of Maritime Accidents", Promet Traffic an\& Transportation Research, Vol. 27, No.2, 113-123.

Özdemir, Ü., (2016), “Çok Kriterli Karar Verme Yöntemleri Kullanılarak Gemileri için Uygun Yük seçiminin Analizi”, PhD. Thesis, Karadeniz Technical University, Trabzon, Octtober (in Turkish).

Özdemir, Ü. (2016), "Bulanık DEMATEL ve Bulanık TOPSIS Yöntemleri KullanılarakLimanlarda Yaşanan İş Kazalarının İncelenmesi”, Journal of ETA Maritime Science, Vol. 4, No. 3, 235-247.

Phillips, D.J. (1990), “The price tag on turnover”, Personnel Journal, 4: 58-61.

Pierce, J. and Aguinis, H. (2013), "The too-much-of-a-good-thing effect in management”, Journal of Management, Vol. 39, No. 2, 313-338.

Rahim, A.M., Civelek, İ and Liang, H.F. (2015), “A model of department chairs' social intelligence and faculty members' turnover intention", Intelligence, Vol. 53, 6571.

Rafiei, S., Pourrezza, A., Kazemzadeh, R.B. and Jahantingh, F.F. (2013), "Evaluation of Power Distance and its consequences on Hospital of Tehran University of 
Medical Sciences", American Journal of Public Health Research, Vol. 1, No. 3, 59-64.

Schwerdt, G. (2011), "Labor turnover before plant closure: "Leaving the sinking ship" vs."Captain throwing ballast overboard", Labour Economics, Vol. 18, No.1, 93101.

Shahraki, A.R. and Paghaleh, M.J.(2011), "Ranking The Voice of Customer With Fuzzy DEMATEL and Fuzzy AHP”, Indian Journal of Science and Technology, Vol. 4, 117-127.

Shieh, J. I., Wu, H. H. and Huang, K. K. (2010), "A DEMATEL method in identifying keysuccess factors of hospital service quality”, Knowledge-Based Systems, Vol. 23:277-282.

Slatten, T. Svensson, G. and Svaeri, S. (2011), "Service quality and turnover intentions as perceived by employees", Antecedents and consequences Personnel Review, Vol. 40, No. 2, 205-221.

Steers, R. and Mowday, R. (1981), "Employee turnover and postdecision accommodation Processes", Research in Organizational Behavior, Vol. 4, 235281.

Şimsek, M. S., Çelik, A. and Akgemci, T. (2001), "Davranış Bilimlerine Giriş ve Örgütlerde Davranış”, Nobel Yayın Dağıtım, 2. Baskı, Ankara, pp.353.

Tatar, V., Özer, M.B., and Gümüşkaya, E. (2015), "Limanlarda İş Sağlığı ve Güvenliği: Hopa Limanı Uygulaması”, II. Ulusal Liman Kongresi, 5-6 Kasım 2015, İzmir. Ting,

W. (2011), “ Top management turnover and firm default risk: Evidence from the Chinese securities market, "China Journal of Accounting Research, Vol 4, No. (1-2), 81-89.

Ting, H. (2013), "CEO turnover and shareholder wealth: Evidence from CEO power in Taiwan”, Journal of Business Research, Vol. 66, No. 12, 2466-2472.

Tziner, A., Rabenu, E., Radomski, R. and Belkin, A. (2015), "Work stress and turnover intentions among hospital physicians: The mediating role of burnout and work satisfaction", Revista de Psicología del Trabajo y de las Organizaciones, Vol. 31, No.3, 207-213.

Wu, W.W. and Lee, Y.T. (2007), "Developing global managers' competencies using the fuzzy DEMATEL method" Expert Systems with Applications, Vol. 32, 499-507.

Yang, Y.P., Shieh, H. M., Leu, J.D. and Tzeng, G.H. (2008), “A novel hybrid MCDM model combined with DEMATEL and ANP with applications", International Journal Operational Research, Vol. 5, No. 3, 160-168.

Yalçın, C. (2005), "Limanlarda Güvenlik Önlemleri, Lisans Tezi, İstanbul Teknik Üniversitesi Gemi İnşaatı ve Deniz Bilimleri Fakültesi, İstanbul.

Yılmaz, B. and Halıcı, A. (2010), "İşücü Devir Hızını Etkileyen Etmenler: Sekreterlik Mesleğinde Bir Araştırma", International Journal of Economic and Administrative Studies, Vol. 2, No.4, 33-40. 
Y.Ju, A. Wang, (2012), "Emergency alternative evaluation under group decision makers: A method of incorporating DS/AHP with extened TOPSIS", Expert System with Applications, Vol. 39, No.1, 1315-1323.

Yong, D. (2006), "Plant location selection based on fuzzy TOPSIS", International Journal of Advanced Manufacturing Technologies, Vol. 28, No. (7-8), 323-326.

Zadeh, L. A. (1965), "Fuzzy sets. Information and Control”, Vol. 8, No. 3, 338-353.

Zaffane, R. M. (1994), "Understanding Employee Turnover: The Need for a Contingency Approach", International Journal On Manpower, Vol. 15, No. (910), 22-37.

Zhang, G. and Lu, J. (2002), “An Integrated Group Decision-Making Method Dealing with Fuzzy Preferences for Alternatives and Individual Judgments for Selection Criteria",Group Decision and Negotiation, Vol. 12, 501-515. 